\title{
Embryo and Endosperm Phytochemicals from Polyembryonic Maize Kernels and Their Relationship with Seed Germination
}

\author{
J. David García-Ortíz ${ }^{1}$, Rebeca González-Centeno ${ }^{1}$, María Alejandra Torres-Tapia ${ }^{2}$, \\ J. A. Ascacio-Valdés ${ }^{1}$, José Espinoza-Velázquez ${ }^{2}$ and Raúl Rodríguez-Herrera ${ }^{1, *}$ \\ ${ }^{1}$ Food Research Department, School of Chemistry, Autonomous University of Coahuila, Saltillo, 25280, México \\ ${ }^{2}$ Plant Breeding Department, Universidad Autonoma Agraria Antonio Narro (UAAAN), Saltillo, 25315, México \\ ${ }^{*}$ Corresponding Author: Raúl Rodríguez-Herrera. Email: raul.rodriguez@uadec.edu.mx
}

Received: 20 July 2021 Accepted: 17 November 2021

\begin{abstract}
Because of the growing worldwide demand for maize grain, new alternatives have been sought for breeding of this cereal, e.g., development of polyembryonic varieties, which agronomic performance could positively impact the grain yield per unit area, and nutritional quality. The objectives of this study were to (1) determine the phytochemicals present in the embryo and endosperm of grain from maize families with high, low, and null polyembryony frequency, which were planted at different locations, and (2) state the relationship between these compounds and seed germination. The extracted phytochemicals from corn were identified by HPLC-MS. The results showed that the genotype with the highest presence of phytochemicals was the brachytic population with high polyembryony called "BAP", which also required less water during the germination process. The number of phytochemicals in both embryo and endosperm tissues was not related to the sowing location where they came from or the type of polyembryony. The number of different phytochemicals depended on the grain tissue from where they were extracted. The chemical compounds found in the different maize tissues were related to the development of the plant, either in roots or nibs because these are mainly associated with the lignin synthesis.
\end{abstract}

\section{KEYWORDS}

Zea mays L; HPLC-MS; locations; kernels; phytochemicals

\section{Introduction}

Currently, maize is one of the three most important cereals around the world due to its economic impact, grain yield per hectare and total grain production, having a grain production of more than 1,147 million tons in 2018 [1,2]. In developing countries, maize is one of the main sources of protein and carbohydrates [3]. One of the phenotypic traits that can increase production and nutritional quality of this commodity is polyembryony [4], since plants with this trait have a prolific seed, which may generate multiple plants per seed [5], promoting the emission of two to four radicles, and these can come out separately or together [6]. Polyembryony is classified as single or multiple depending on the number of individuals generated during development [7]. Furthermore, for genotypes with this trait, the number of seeds necessary to cover one surface area unit can be reduced [4], which may reduce cropping costs. The expression of polyembryony has been observed in greenhouse plantings at a frequency greater than $75 \%$, while, in 
direct planting under field conditions, this trait expression is observed between $55 \%$ to $60 \%$ [8]. It has been proposed that polyembryony expression can be related to the pollinator type, amount of available pollen, plant nutrition, environmental temperature, soil moisture, and environmental conditions [9]. However, it has been reported that inheritance of polyembryony is controlled by two epistatic loci of the duplicate dominance type. This is in such a way that the phenomenon is manifested by doubly homozygous recessive genotypes [10-12], which is transferred through sexual reproduction [13]. Maceda-Sánchez et al. [14] mentioned that the genetic background of the parents may have an effect on polyembryony penetrance and that in populations with high polyembryony, the expression of this trait was not affected by the environment.

Grain modifications have been reported in polyembryonic maize families These modifications include higher nutritional quality, increased portions of lysine and tryptophan [15] and higher content of fiber, protein, fat and ashes [16]. These grain traits make polyembryonic maize genotypes a viable option for production of different foods with acceptable physical, chemical and functional characteristics [17]. There are some reports on the nutritional composition of polyembryonic maize grains. However, there is a lack of information about the water requirements during the seed germination of these varieties, as well as the content of phytochemicals according to location and if phytochemicals are related to any other characteristic such as: geobotanical conditions of the environment and soil characteristics [18]. This is of utmost importance since polyembryonic varieties could be used for elaboration of functional foods. With the aforementioned information, the present study was carried out under the following objectives: to (1) determine the phytochemicals present in the embryo and endosperm of the grain from different maize genotypes with high, low and no polyembryony, which were planted at two different locations, and (2) relate the presence of these compounds with seed germination.

\section{Materials and Methods}

\subsection{Vegetal Material}

In this research, two different but related studies were carried out as described below.

\subsubsection{Polyembryony Effect on Seed Germination}

In this trial, seeds of five genotypes were used: (1) 2 families with high polyembryony frequency (both with a polyembryony frequency greater than $60 \%$, one with short plant height, called "BAP" and another with normal plant height, called "NAP") [8], (2) 2 families with low polyembryony (G4.16-2 and G4.1-2, both with a polyembryony frequency of less than 40\%) [12] and (3) a non-polyembryonic maize genotype used as a control ("Garañón", a commercial hybrid from Asgrow). All five genotypes will be referred to as Group 1. Except for the commercial genotype used as the control, all these genotypes were developed at the Mexican Maize Institute Antonio Narro Agrarian Autonomous University (IMMUAAAN) and were sowed at Buenavista, Saltillo, Coahuila $\left(25^{\circ} 22^{\prime \prime} \mathrm{N}, 101^{\circ} 02^{\prime \prime} \mathrm{W}, 1,756\right.$ m.a.s.l. At this location, the weather is dry, semi-arid, and the soil has a clay loam texture with a low organic matter content. The experiment was established under a randomized complete block design with three replications. Row length was $5 \mathrm{~m}$ with a distance between rows of $0.80 \mathrm{~m}$. The agronomical practices were those recommended for this locality [16].

\subsubsection{Determination of Phytochemicals in Different Structures of Maize Kernel}

Six families of corn were used from two different populations (3 families from each population). These populations were planted and harvested in 2017. The first population was made up of plants with normal height and high polyembryony (NAP), and the second population with plants with normal height, but without polyembryony or non-polyembryony (NBP). These populations were developed at the Mexican Maize Institute-the Antonio Narro Agrarian Autonomous University (IMM-UAAAN). The 3 NAP families were identified as $\mathrm{C}-1, \mathrm{C}-2$, and $\mathrm{C}-3$. These genotypes together will be hereinafter called 
Group 2, while the 3 NBP families such as A-1, A-2, and A-3 genotypes will be called hereinafter Group 3. In addition, the 5 genotypes mentioned in the previous study, named as Group 1, were also used. Just to remember, this group was composed of 2 families of high polyembryony (BAP and NAP), 2 families of low polyembryony (G4.16-2 and G4.1-2), and the non-polyembryonic commercial hybrid "Garañón"Asgrow (GON).

The 6 families were planted under irrigation conditions, in Río Bravo, Tamaulipas ( $25^{\circ} 57^{\prime \prime} \mathrm{N}, 98^{\circ} 01^{\prime \prime}$ W, 26 m.a.s.1, where the weather is semi-arid, subtropical warm with vertisol soil with clay texture) and Buenavista, Coahuila $\left(25^{\circ} 22^{\prime \prime} \mathrm{N}, 101^{\circ} 02^{\prime \prime} \mathrm{W}, 1,756\right.$ m.a.s.l., where the weather is dry, semi-arid, the soil has a clay loam texture with low organic matter content). In this last location, Group 1 was also planted. Each experiment was established under a randomized complete block design with three replications, with a row length of $5 \mathrm{~m}$, a distance between rows of $0.80 \mathrm{~m}$, and a distance between plants of 15 and $17 \mathrm{~cm}$ for NBP and NAP, respectively. Agronomic practices were those recommended for each location [16].

\subsection{Evaluated Variables}

\subsubsection{Viability and Imbibition of Seeds}

Seeds (BAP, NAP, GON, G4.16-2 and G4. 1-2) which structure did not show any type of physical damage were selected, and twenty seeds were placed on germination paper. The paper was watered by spraying distilled water added with a Tecto $60 \%$ solution (thiabendazole), the paper was rolled up and formed into a roll. The rolls were placed vertically in bags supported by a container, which was placed in an Ecoshel bioclimatic chamber. The chamber was programmed under two cycles with the following conditions: $12 \mathrm{~h}, 25^{\circ} \mathrm{C}, 80 \% \mathrm{Hw}$ (relative humidity), alternating the amount of light in each cycle from 0 to 3 lux (0 lux during darkness period and 3 lux during the light period). After 7 days, the seed germination percentage was documented, which showed root and plumule development. Later, another study about the water requirements of polyembryonic genotypes (BAP, NAP, GON, G4.16-2 and G4. 1-2) during germination was carried out. The genotypes were placed in a germination chamber (with two cycles: $12 \mathrm{~h}, 25^{\circ} \mathrm{C}, 80 \% \mathrm{Hw}$ and alternating the amount of light in each cycle from 0 to 3 lux) and using a kinetics study [19], the water absorption by the seed was observed over time. In this step, the individual weight of 20 seeds from each genotype was initially evaluated. Thereafter, the amount of water absorbed by each seed was determined by the difference in weights using an analytical balance and taking the initial weight as a reference. This was performed every $2 \mathrm{~h}$ during a period of $28 \mathrm{~h}$. The amount of water absorbed by the seed was expressed as a percentage of increase in the weight of the seed, by absorption of water, in comparison to the initial weight [19].

\subsubsection{Determination of Phytochemicals}

The maize kernels were softened by placing them in water for $12 \mathrm{~h}$. After this, the tip was cut with a scalpel and the embryo, pericarp, and endosperm were removed. Subsequently, embryo and endosperm were ground, using a blender for grinding embryos. Meanwhile, a mortar was used for grinding the endosperm. Later, embryo and endosperm powders were used to prepare extracts in a 1:7 ratio (grams of the sample: milliliters of the solvent). The solvent was a 70:30 mixture of methanol-water. For the phytochemical determination of each sample, first, $1.8 \mathrm{~mL}$ of the sample extract wasfiltered using nylon filters $(0.45 \mu \mathrm{m})$ and the filtrate was placed into the equipment vials. Samples were sent for analysis using an HPLC (Varian Prostar, model 330), which has a UV-visible diode array detector $(280 \mathrm{~nm})$, and is coupled to a mass detector (Varian, model 500-MS). Compounds separation was carried out on a Grace Denali C-18 column $(5 \mu \mathrm{m}, 250 \mathrm{~mm} \times 4.6 \mathrm{~mm})$ at $30^{\circ} \mathrm{C}$. Methanol was used as a washing solution and the different relations of acetonitrile (B) and acetic acid 3\% (C) were used in the mobile phase (initial 3\% $\mathrm{B}$ and $97 \% \mathrm{C}, 0-5 \min 9 \% \mathrm{~B}$ and $91 \% \mathrm{C}, 5-15 \min 16 \% \mathrm{~B}$ and $84 \% \mathrm{C}, 15-30 \mathrm{~min} 33 \% \mathrm{~B}$ and $67 \% \mathrm{C}$, $30-33 \mathrm{~min} 90 \% \mathrm{~B}$ and $10 \% \mathrm{C}, 33-35 \mathrm{~min} 90 \% \mathrm{~B}$ and $10 \% \mathrm{C}, 35-42 \mathrm{~min} 3 \% \mathrm{~B}$ and $97 \% \mathrm{C}$ ). The flow rate was $1 \mathrm{~mL} / \mathrm{min}$, and the injection volume was $10 \mu \mathrm{L}$. Mass analysis was performed using a Varian 
500-MS ion trap kit, electrospray ionization (ESI), capillary voltage $90 \mathrm{~V}$, negative mode ([MH]-m/z), and mass acquisition range $100-2000 \mathrm{~m} / \mathrm{z}$.

\subsection{Statistical Analysis}

Firstly, the presence or absence of a specific phytochemical was coded in a binary system $(0=$ absence and $1=$ presence). Then, a categorical analysis of data was performed using $\mathrm{S} \times \mathrm{R}$ tables to determine the effect of tissue (embryo and endosperm), location (BV or RB) and level of polyembryony (high, low and null) on the number of different kernel phytochemicals. The analyzes were performed using SAS software version 9.0. Experiment for polyembryony effect on seed germination was established under a complete randomized block design with three replications, data were transformed by arcsine (square root $(\mathrm{y}+0.5))$ then ANOVA was performed, the significance level was $P<0.05$.

\section{Results and Discussion}

\subsection{Polyembryony Effect on Seed Germination (Seed Viability and Imbibition)}

A seed germination percentage above $95 \%$ was observed in all genotypes (Table 1), which suggests that seed production and storage conditions were adequate. These high percentages of germination observed under laboratory conditions could be attributed to the fact that the germination process developed in the absence of stress conditions (water, light, physical, thermal stress, etc.), which could also justify the high polyembryony frequency observed. It has been documented that environmental conditions have an effect on the expression of polyembryony. A higher frequency of polyembryony has been observed when sowing under greenhouse than under field conditions [8]. One possibility because of the less polyembryony frequency observed under more adverse environments is that (although this characteristic is genetically determined) the possibility that the shoots are free from stress conditions is not exempt. If this is the case, it limits the germination or growth of some twin seed buds reducing the percentage of PEm.

Table 1: Percentage of seed germination and polyembryony of 5 maize genotypes after 7 days of sowing

\begin{tabular}{|c|c|c|}
\hline Genotype & PEm $(\%)$ & Germination $(\%)$ \\
\hline BAP & 80 & 100 \\
\hline NAP & 80 & 100 \\
\hline G4. 16-2 & 70 & 100 \\
\hline G4. 1-2 & 63.2 & 95 \\
\hline GON & 0 & 100 \\
\hline
\end{tabular}

There are three phases in germination. In the first phase, there is a rapid absorption of water, in phase two, there is a decrease in absorption, and this is when the seed metabolic processes are activated, while in the third phase, tissue synthesis is promoted for the development of the radicle (the primary root of the seminal root system), again requiring considerable water absorption [20].

Imbibition of seeds (from five genotypes) was determined according to the method reported by RosabalAyan et al. [20]. In this study, it was observed a rapid increase in the water absorption of grains, later, it was possible to observe, how this absorption level begins to decrease almost completely, and then, water is absorbed again. During the germination process, the beginning of Phase 1 was observed, increasing the 
absorption of water during the first $4 \mathrm{~h}$, after this time, Phase $1 \mathrm{l}$ began as shown in Fig. 1, in the NAP, G416-2 and G4. 1-2 genotypes, while in BAP and GON this phase begins around the 8th-h. The G. 16-2 and G4. 1-2 genotypes showed similar behavior, and at the process end, both of these genotypes, and the high-polyembryonic families reduced their water absorption again between the 20th and 25th-hour. Matilla [21] mentions that after the first two stages of germination, the seed resumes an increase in water absorption which corresponds to the elongation phase, after observing the variations in water absorption allows us, to suppose that the process of lengthening in these families slows down to carry out metabolic processes, this could occur since multiple developments are required.

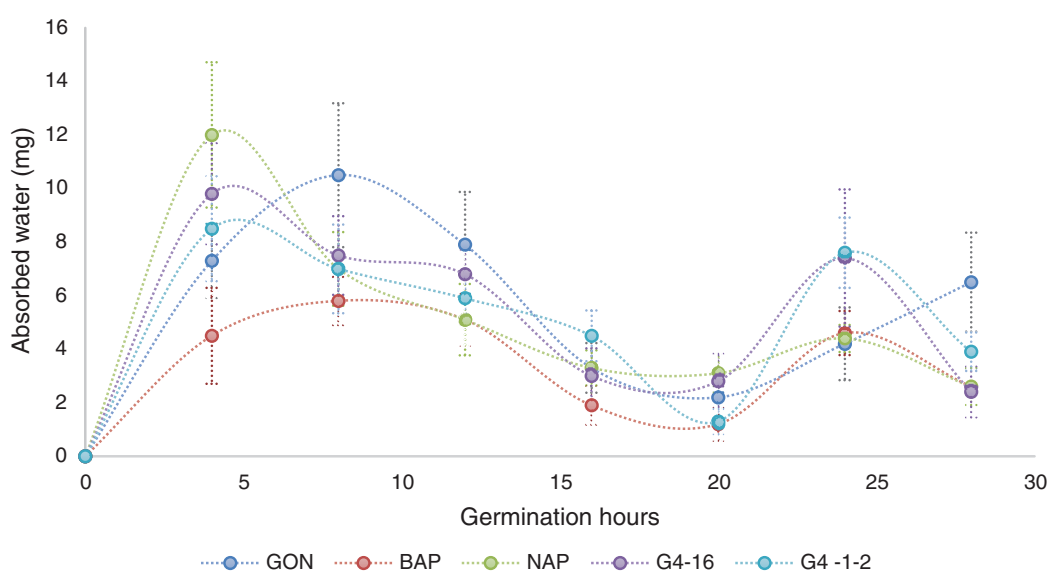

Figure 1: Water absorbed during the germination process by grains from 5 genotypes with different levels of polyembryony. $\mathrm{BAP}=$ Corn with high polyembryony frequency and short plant height. NAP $=$ Corn with high polyembryony frequency and normal plant height. G4. 1-2=Corn with low polyembryony frequency. G4. 16-2=Corn with low polyembryony frequency. GON = Commercial and nonpolyembryonic maize hybrid from Asgrow

The BAP genotype required less water as shown in Fig. 2, this genotype needed up to 23\% less water than other genotypes. Fenner et al. [22] reporter that the amount of water absorbed by the seed and the absorption speed is due not only to environmental factors during germination, but also to seed membrane permeability, chemical composition, and genotype characteristics. This trait is a great advantage for production, as BAP is a brachytic maize genotype, which during its growth maintains a short size, compared to those of normal size, in addition to the results obtained in the laboratory, we could appreciate that this genotype requires a lower amount of water during its germination process. Despite the data obtained, it cannot be guaranteed that this variety is a viable option as a crop in regions with low rainfall, or with little availability of irrigation water, due to the fact that the study was carried out under controlled conditions, it is recommended more research under field conditions.

\subsection{Determination of Phytochemicals in Different Structures of Maize Kernel}

The 15 compounds detected in grain tissues from genotypes with different degrees of polyembryony (Group 1), using HPLC mass analyses, were identified according to their molecular mass ( $\mathrm{g} \mathrm{mol}^{-1}$ and retention time $(\min )($ Table 2$)$. 


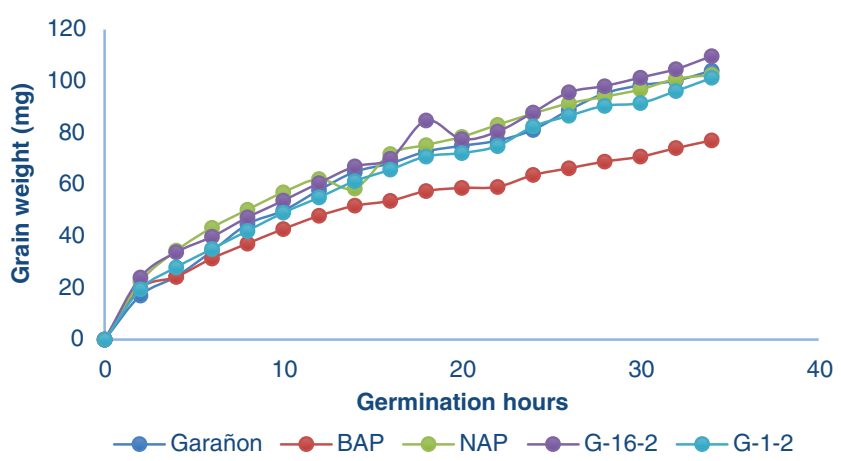

Figure 2: Grain weight from 5 genotypes with different levels of polyembryony, after being imbibed in water during the germination process. BAP $=$ Corn with high polyembryony frequency and short plant height. NAP $=$ Corn with high polyembryony frequency and normal plant height. G4. 1-2= Corn with low polyembryony frequency. G4. 16-2 = Corn with low polyembryony frequency. GON = Commercial and non-polyembryonic hybrid maize from Asgrow. Only BAP was statistically different from the others genotypes

Table 2: Compounds were found in different grain tissues from 5 genotypes with different levels of polyembryony. BAP $=$ Corn with high polyembryony frequency and short plant height. NAP $=$ Corn with high polyembryony frequency and normal plant height. G4. 1-2 = Corn with low polyembryony frequency. G4. 16-2= Corn with low polyembryony frequency. GON = Commercial and nonpolyembryonic maize hybrid from Asgrow

\begin{tabular}{|c|c|c|c|c|c|c|c|}
\hline Tissue & Compound & Family & BAP & NAP & G4. 1-2 & G4. $16-2$ & GON \\
\hline \multirow{14}{*}{ Embryo } & 3,4-DHPEA-EA & Tyrosols & 1 & 1 & 1 & 1 & 1 \\
\hline & Scopoletin & Hydroxycoumarins & 1 & 1 & 0 & 0 & 1 \\
\hline & p-coumaroil tartaric acid & Hydroxycoumarins & 1 & 1 & 0 & 0 & 0 \\
\hline & 5-5'-dehydrodiferulic acid & Hydroxycinnamic acids & 1 & 1 & 0 & 0 & 0 \\
\hline & Apigenin 6-C-glucoside & Methoxycinnamic acid dimers & 0 & 0 & 0 & 1 & 0 \\
\hline & Transfertaric acid & Methoxycinnamic acids & 1 & 1 & 1 & 1 & 1 \\
\hline & 3-Feruloylquinic Acid & Methoxycinnamic acids & 1 & 1 & 1 & 1 & 0 \\
\hline & 1-caffeoylquinic acid & Hydroxycinnamic acids & 1 & 0 & 0 & 0 & 1 \\
\hline & Isorhamnetin 3-O-glucuronide & Methoxyflavonols & 1 & 1 & 1 & 0 & 1 \\
\hline & Quercetin 3-O-(6"-malonyl-glucoside) & Tyrosols & 0 & 0 & 0 & 1 & 0 \\
\hline & 3-caffeoylquinic acid & Flavonols & 1 & 1 & 0 & 0 & 0 \\
\hline & Phloridzin & Hydroxycinnamic acids & 1 & 0 & 1 & 1 & 1 \\
\hline & Luteolin 7-O-diglucuronide & Dihydrochalcones & 1 & 0 & 0 & 1 & 0 \\
\hline & $(+)$-Catechin 3-O-gallate & Flavones & 1 & 1 & 0 & 1 & 0 \\
\hline \multirow{5}{*}{ Endosperm } & 3,4-DHPEA-EA & Catechins & 1 & 1 & 1 & 1 & ud \\
\hline & Caffeic acid 4-O-glucoside & Tirosoles & 0 & 1 & 0 & 0 & ud \\
\hline & 3-Feruloylquinic Acid & Hydroxycinnamic acids & 0 & 0 & 1 & 0 & ud \\
\hline & Phloridzin & Hydroxycinnamic acids & 1 & 1 & 0 & 1 & $\mathrm{ud}$ \\
\hline & $(+)$-Catechin 3-O-gallate & Dihydrochalcones & 1 & 1 & 0 & 1 & ud \\
\hline
\end{tabular}


Embryo. In grains from Group 1 genotypes, 3,4-DHPEA-EA and feruloyl tartaric acid were found in all genotypes, Isorhamnetin 3-O-was found in most of the genotypes. While, glucuronide was found in most of the genotypes, except for the G4. 16-2 genotype, 3-feruloylquinic acid, except for the genotype (control) and Phloridzin, except for the NAP genotype. In addition, p-coumaroyl tartaric acid, 5-5'-dehydrodiferulic acid, scopoletin, (+)-Catechin 3-O-gallate, and 3-caffeoylquinic acid were found in the high polyembryonic genotypes (BAP and NAP). While in G4. 16-2 in addition to those already mentioned, Apigenin 6-Cglucoside, Luteolin 7-O-diglucuronide, and Quercetin 3-O-(6"-malonyl-glucoside) were found, the latter was also found in the BAP genotype.

By HPLC, the presence of twelve different phytocompounds (Table 2) was detected in the BAP genotype, while only nine in NAP, six in the Garañón hybrid, five in G4. 1-2, and eight in the G4. 16-2. The greater number of phytochemicals found in BAP could be related to its lower water requirement during the germination process, in comparison to the rest of the genotypes tested. The presence of these phytochemicals is related to the formation of plant tissue, most of them being precursors of ferulic acids in cell walls [23]. Coumarins and cinnamic acids synthesized during plant development participate in the metabolic pathway for lignin production [24]. In addition, the presence of hydroxycinnamic acids (pcoumaroyl tartaric acid, 3-caffeoylquinic acid, and 3-feruloylquinic acid) present in the highpolyembryony genotypes, could be due to the accelerated production of plant tissue, necessary to cover the characteristics of these individuals, being able to be substrates for scopoletin synthesis and are found as metabolites secreted by roots [25].

Endosperm. Three compounds were determined in this tissue in the BAP genotype, four in the NAP genotype, two in G4. 1-2, and 3 in G4. 16-2. In this case, 3,4-DHPEA-EA was found in all genotypes, caffeic acid 4-O-glucoside present only in NAP, 3-feruloylquinic acid in G4. 1-2, while Phloridzin as (+)-Catechin 3-O-galate in the endosperms of BAP, NAP, and G4. 16-2. At this stage, phytochemicals in the Garañon genotype endosperm could not be analyzed, because, it is a commercial cultivar, and the seed is treated with fungicides and insecticides to preserve health, which interfered with the HPLC mass analysis.

Presence of great diversity of phytochemicals found in the grains of the BAP genotypes may be indicative that more processes are being carried out in the production of plant tissue [24], in addition, presence of these not only influences the routes of tissue production, if they are not also related in their ability to resist water stress, as well as some other environmental factors, some of these may be associated with the presence of phenolic compounds during germination. Therefore, the greater presence of these compounds suggests relevant biochemical mechanisms for the responses [26]. Polyembryonic and non-polyembryonic maize genotypes. The compounds detected in the grain tissues of polyembryonic and non-polyembryonic genotypes (Groups 2 and 3), grown at two different locations are shown in Table 3. On the other hand, a concentrate of the total number of phytochemicals found in the genotypes with different levels of polyembryony, tissues, and grains grown at different locations is shown in Table 4. The numerical census of the phytocompounds found in the grains from polyembryonic and nonpolyembryonic genotypes (Groups 2 and 3) was very similar (57 and 59 compounds, respectively) (Table 4), the 3,4-DHPEA-EA compound was found more frequently (twelve compounds in PEm and ten in Non-PEm), followed in frequency by phloridzin (seven times in PEm and eleven in Non-PEm), (+)-catechin 3-O-galate (eight times in PEm and six in Non-PEm) and caffeic acid 4-O-glucoside (eight times in PEm and seven Non-PEm) (Table 3). 3-Feruloylquinic acid (five times) and 1-caffeoylquinic acid (four times) were similarly found in polyembryonic and non-polyembryonic, and those found less frequently were scopoletin and p-coumaroyl tyrosine. Furthermore, the 3-caffeoylquinic acid compounds, p-coumaroyl tyrosine, and sinensetine were only found once in grains from non-polyembryonic genotypes, while the Rosmadial compound only appeared once in polyembryonic genotypes. 
Table 3: Phytochemicals found in the different tissue of grains from PEm and Non-PEm maize genotypes produced at different location

\begin{tabular}{|c|c|c|c|c|c|c|c|c|c|c|c|c|c|c|}
\hline \multirow[t]{3}{*}{ Tisues } & \multirow[t]{3}{*}{ Code } & \multirow[t]{3}{*}{ Compound } & \multicolumn{6}{|c|}{ Rio bravo } & \multicolumn{6}{|c|}{ Buenavista } \\
\hline & & & \multicolumn{3}{|c|}{ No-PEm } & \multicolumn{3}{|c|}{ PEm } & \multicolumn{3}{|c|}{ No-PEm } & \multicolumn{3}{|c|}{ PEm } \\
\hline & & & A1 & $\mathrm{A} 2$ & A3 & $\mathrm{C} 1$ & $\mathrm{C} 2$ & $\mathrm{C} 3$ & A1 & $\mathrm{A} 2$ & A3 & $\mathrm{C} 1$ & $\mathrm{C} 2$ & $\mathrm{C} 3$ \\
\hline \multirow{14}{*}{ Embrio } & A & 3,4-DHPEA-EA & 1 & 1 & 1 & 1 & 1 & 1 & 1 & 1 & 1 & 0 & 0 & 1 \\
\hline & $\mathrm{B}$ & S5copoletin & 1 & 0 & 0 & 0 & 0 & 0 & 0 & 0 & 0 & 0 & 1 & 0 \\
\hline & $\mathrm{D}$ & 5-5'-dehydrodiferulic acid & 0 & 0 & 0 & 1 & 1 & 1 & 1 & 0 & 0 & 0 & 0 & 0 \\
\hline & $\mathrm{E}$ & Feruloyl tartaric acid & 0 & 1 & 0 & 1 & 0 & 1 & 0 & 1 & 0 & 0 & 0 & 1 \\
\hline & $\mathrm{F}$ & 3-Feruloylquinic Acid & 1 & 0 & 0 & 1 & 1 & 1 & 1 & 1 & 1 & 1 & 0 & 0 \\
\hline & G & 1-caffeoylquinic acid & 1 & 1 & 1 & 1 & 1 & 1 & 1 & 0 & 1 & 0 & 1 & 1 \\
\hline & $\mathrm{H}$ & Isorhamnetin 3-O-glucuronide & 1 & 1 & 1 & 0 & 0 & 1 & 1 & 0 & 1 & 1 & 1 & 0 \\
\hline & I & 3-caffeoylquinic acid & 0 & 1 & 0 & 0 & 0 & 0 & 0 & 0 & 0 & 0 & 0 & 0 \\
\hline & $\mathrm{J}$ & Phloridzin & 1 & 1 & 1 & 1 & 0 & 0 & 1 & 1 & 1 & 1 & 1 & 1 \\
\hline & $\mathrm{L}$ & $(+)$-Catechin 3-O-gallate & 0 & 0 & 0 & 1 & 1 & 0 & 1 & 1 & 0 & 1 & 0 & 1 \\
\hline & $\mathrm{O}$ & Caffeic acid 4-O-glucoside & 0 & 0 & 1 & 1 & 1 & 1 & 1 & 1 & 1 & 1 & 0 & 1 \\
\hline & $\mathrm{P}$ & $(+)$-Gallocatequina & 1 & 1 & 0 & 0 & 0 & 1 & 1 & 0 & 0 & 0 & 0 & 0 \\
\hline & Q & p-Coumaroyl tyrosine & 0 & 0 & 0 & 0 & 0 & 0 & 1 & 0 & 0 & 0 & 1 & 0 \\
\hline & $\mathrm{R}$ & d-viniferin & 0 & 0 & 0 & 0 & 0 & 0 & 1 & 0 & 0 & 0 & 0 & 0 \\
\hline \multirow{6}{*}{ Endosperm } & A & 3,4-DHPEA-EA & 1 & 1 & 1 & 1 & 1 & 1 & 1 & 1 & 1 & 1 & 1 & 1 \\
\hline & $\mathrm{J}$ & Phloridzin & 1 & 1 & 1 & 0 & 0 & 0 & 0 & 1 & 1 & 1 & 1 & 1 \\
\hline & $\mathrm{L}$ & $(+)$-Catechin 3-O-gallate & 0 & 1 & 1 & 1 & 1 & 0 & 1 & 0 & 1 & 0 & 1 & 1 \\
\hline & $\mathrm{O}$ & Caffeic acid 4-O-glucoside & 1 & 0 & 1 & 1 & 1 & 0 & 0 & 0 & 1 & 1 & 0 & 0 \\
\hline & $\mathrm{S}$ & Rosmadial & 0 & 0 & 0 & 0 & 0 & 0 & 1 & 0 & 0 & 0 & 0 & 0 \\
\hline & $\mathrm{T}$ & Sinensetin & 0 & 0 & 0 & 0 & 0 & 1 & 0 & 0 & 0 & 0 & 0 & 0 \\
\hline
\end{tabular}

Note: $\mathrm{PEm}=$ Polyembryonic. No-PEm $=$ Non-polyembryonic. $1=$ presence, $0=$ absence.

Table 4: Number of times that a specific compound was found, in polyembryonic and non-polyembryonic maize grain, in embryo and endosperm, and in grains from genotypes grown at two different locations

\begin{tabular}{|c|c|c|c|c|c|c|}
\hline \multirow[t]{2}{*}{ Code } & \multicolumn{2}{|c|}{ Polyembryony } & \multicolumn{2}{|c|}{ Tissue } & \multicolumn{2}{|c|}{ Location } \\
\hline & PEm & No-PE & Embryo & Endosperm & Rio Bravo & Buenavista \\
\hline A & 12 & 10 & 10 & 12 & 12 & 10 \\
\hline B & 1 & 1 & 2 & 0 & 1 & 1 \\
\hline $\mathrm{D}$ & 3 & 1 & 6 & 0 & 3 & 1 \\
\hline $\mathrm{E}$ & 3 & 2 & 5 & 0 & 3 & 2 \\
\hline $\mathrm{F}$ & 4 & 4 & 8 & 0 & 4 & 4 \\
\hline G & 5 & 5 & 10 & 0 & 6 & 4 \\
\hline
\end{tabular}




\begin{tabular}{|c|c|c|c|c|c|c|}
\hline \multirow[t]{2}{*}{ Code } & \multicolumn{2}{|c|}{ Polyembryony } & \multicolumn{2}{|c|}{ Tissue } & \multicolumn{2}{|c|}{ Location } \\
\hline & PEm & No-PE & Embryo & Endosperm & Rio Bravo & Buenavista \\
\hline $\mathrm{H}$ & 3 & 5 & 8 & 0 & 4 & 4 \\
\hline I & 0 & 1 & 1 & 0 & 1 & 0 \\
\hline $\mathrm{J}$ & 7 & 11 & 10 & 8 & 7 & 11 \\
\hline $\mathrm{L}$ & 8 & 6 & 6 & 8 & 6 & 8 \\
\hline $\mathrm{O}$ & 8 & 7 & 9 & 6 & 8 & 7 \\
\hline $\mathrm{P}$ & 1 & 3 & 4 & 0 & 3 & 1 \\
\hline Q & 1 & 1 & 2 & 0 & 0 & 2 \\
\hline $\mathrm{R}$ & 0 & 1 & 0 & 1 & 0 & 1 \\
\hline $\mathrm{S}$ & 1 & 0 & 0 & 1 & 0 & 1 \\
\hline $\mathrm{T}$ & 0 & 1 & 0 & 1 & 1 & 0 \\
\hline Total & 57 & 59 & 81 & 37 & 59 & 57 \\
\hline
\end{tabular}

Note: $\mathrm{PEm}=$ Polyembryonic. No-PEm $=$ Non-polyembryonic.

Phytochemicals found in embryo and endosperm. A greater total number of phytocompounds was found in the embryo (81 phytocompounds), while only 37 were found in the endosperm (Table 4). In both tissues, compounds such as 3,4-DHPEA-EA, phloridzin, $(+)$-catechin 3-O-gallate, caffeic acid 4-O-glucoside and, $(+)$-gallocatechin were found. In addition to those mentioned, in the embryo were found: scopoletin, 5-5'dehydrodiferulic acid, feruloyl tartaric acid, 3-feruloylquinic acid, 1-caffeoylquinic acid, isorhamnetin 3O-glucuronide, 3-caffeoylquinic acid, (+)-gallocatechin and p-goumaroyl tyrosine, while in endosperm were found: (+)-catechin 3-O-gallate, caffeic acid 4-O-glucoside, d-viniferin, rosmadial, and sinensetine.

Sowing location. The total number of phytocompounds found in grains produced in both, Rio Bravo (RB) and Buenavista (BV) locations do not differ much from each other, being these 59 and 57, respectively (Table 4). In both environments, in higher frequency were found 3,4-DHPEA-EA (twelve times in RV and 10 in BV), Phloridzin (seven in RV and eleven in BV), (+)-Catechin 3-O-gallate (six in $\mathrm{RV}$ and eight in BV) and 4-O-glucoside caffeic acid (eight in RV and seven in BV) and in less frequency Scopoletin (1 time in both locations), 5-5'-dehydrodiferulic acid (three in RV and one in BV), feruloyl tartaric acid (three in RV and two in BV), 3-feruloylquinic acid (4 in both locations), 1-caffeoylquinic acid (six in RV and four in BV), isorhamnetin 3-O-glucuronide (4 times in both locations), (+)-Gallocatechins (three in RV and one in BV). In addition, the acidic compounds: 3-caffeoylquinic (two times), d-viniferin (one time) and Rosmadial (one time) were only found in maize grain produced in the Buenavista location, as well as, 3-caffeoylquinic acid (one time) and sinensetine compounds (one time) were only found in grains from the Rio Bravo location (Table 3). In this regard, Wichers et al. [27], reported the presence of 3,4-DHEA-EA as a predecessor antioxidant of different phenolic compounds in olive trees. Ba et al. [28] mentioned that Scopoletin found in cassava roots has an inhibitory activity of sporulation and mycelial growth. While, Goodwin et al. [29] documented this compound in the region of cell lengthening, being able to attribute it, to the formation of root tissue, in addition, Dennis et al. [25] found this compound in root secretions. Dewick [24] reports the bacteriostatic effect of this compound; Besides, scopoletin is mentioned as a precursor of curamic-4 acid, which in interaction with tartaric acid produces p-Coumaroyl tartaric acid, which is a cinnamic acid that plays a role in the metabolite pathway for lignin production. Hatfield et al. [23] mentioned the presence of different ferulic acids in cell walls of 
grasses, like in Crowfoot grass (Dactyloctenium aegyptium) and maize, which form polysaccharide chains. Frangne et al. [30] studying barley, indicated that aspergenin-6-c-glucoside acts as an antioxidant, and is also involved in the transport of secondary compounds in vacuoles. For its part, feruloyl tartaric acid is a product of the synthesis of l-tartaric acid, which is found in grass tissues [24].

Hydroxycinnamic acids are associated with plant growth and development and in response to senescence and drought stress [31]. Furthermore, Macoy et al. [32] reported that these same acids are secondary metabolites derived from the phenylalanine and tyrosine pathway, which are precursors of different alkaloids against pathogens, and participate in plant pigmentation. On the other hand, Fellah et al. [33] document thyrosols as strong antioxidants in pomegranate. Flavonoids naturally produce watersoluble glucosides, these being a variant of flavones, flavanones, anthocyanidins, and catechins. In addition, it has been mentioned that the presence of different catechins, such as (+) catechin 3-O-gallate, could promote inhibition of $\alpha$-amylase and $\alpha$-glucosidase, in tissues of Parapiptadenia rigida. Sinensetine was reported in Orthisiphun aristus and was associated with different stress conditions such as light [34]. Rosmadial and Gallocatechins have been reported for their antioxidant activity in sea buckthorn [35]. Most of the compounds found in this experimental step are associated with antioxidant activities, as well as, growth or formation of different tissues, participating during the formation of plant structures [24].

The total number of phytochemicals in grains from maize genotypes with different degrees of polyembryony was compared using a categorical analysis (Table 5), where, the Qs are marked as MantelHaenszel Chi-square, the Pearson Qp-square value is labeled "Chi-square". Qs has a value of 0.2784 and $P=0.5978$; Qp has a value of 12.0376 and $P=0.6762$, which indicates that there is no significant relationship in the total number of phytochemicals with the presence of polyembryony. Likewise, in the statistical analysis comparing the total number of phytochemicals in maize grains produced at different locations, a Qs value of 0.9978 and $P=0.3178$ was observed, and Qp of 6.9944 and $P=0.9349$, demonstrating that there is no relationship in the total number of phytochemicals, with the locality where the maize grains were produced.

Table 5: Statistical significance in the different categorical analyzes of the total number of phytochemicals found in maize grains from genotypes with different degrees of polyembryony

\begin{tabular}{lllll}
\hline Statistical & Gl & $\begin{array}{l}\text { Polyembryony } \\
\text { by phytochemical }\end{array}$ & $\begin{array}{l}\text { Location by } \\
\text { phytochemical }\end{array}$ & $\begin{array}{l}\text { Tissue by } \\
\text { phytochemical }\end{array}$ \\
\hline Chi-squared & 15 & 0.6762 & 0.9349 & 0.0061 \\
Chi-square likelihood ratio & 15 & 0.4870 & 0.8558 & 0.0002 \\
Chi-square mantel-haenszel & 1 & 0.5978 & 0.3178 & 0.4566 \\
Coefficient Phi & & 0.3470 & 0.2557 & 0.5671 \\
Contingency coefficient & & 0.3278 & 0.2477 & 0.4933 \\
Cramer's V & & 0.3470 & 0.2557 & 0.5671 \\
\hline
\end{tabular}

When the total number of compounds found in the embryo was compared with those found in the endosperm, a Qs with a value of 0.5543 and $P=0.4566$ was observed, and a Qp with 33.1615 and $P=0.0061$, showing that there is a greater number of phytochemicals in the embryo than in the endosperm, this is because the embryo, being the place where embryogenesis takes place, is an active tissue, requiring the presence of different compounds in order to carry out its functions. Fourteen different compounds were obtained in the embryo, while in the endosperm only 6. Finding 3,4-DHPEA-EA, Phloridzin, (+)-Catechin 3-O-gallate, Caffeic acid 4-O-glucoside in both tissues. In addition to these, Rosmadial and Sinensetine were found in the endosperm. While in the embryo were found scopoletin, 
5-5'-dehydrodiferulic acid, feruloyl tartaric acid, 3-feruloylquinic acid, 1-caffeoylquinic acid, 3caffeoylquinic-3-O-glucuronide quinic acid, $(+)$-Gallocatechin, p-Coumarol tyrosine, and d-Viniferin. This could indicate that the embryo needs more phytochemicals to develop the radicle and plumule during germination.

\section{Conclusions}

The chemical compounds found in grains from different maize genotypes suggest that these phytochemicals are involved in root and plumule tissue development since some of these components have been associated with the metabolic pathways for plant tissue development. The higher number of compounds found in the BAP genotype suggests that they are needed for early growth of plant tissues, these being reported in the route for lignin synthesis, which would justify its low water requirement during the germination process. The data analysis supports a statistical difference between the numbers of compounds found in the embryo and the endosperm, being higher in the former structure, but there was not found any direct relationship between the number of phytochemicals and polyembryony levels, and nor with sowing locations where grains were produced.

Funding Statement: JDGO thanks to the National Council of Science and Technology (CONACyT)Mexico for the financial support during his BSc studies. This project had financial support from SEPCONACyT through the project "Identification and sequencing of DNA regions that control polyembryony in corn". FON.SEC. SEP-CONACYT CV-2015-256081.

Conflicts of Interest: The authors declare that they have no conflicts of interest to report regarding the present study.

\section{References}

1. FAO (Organización de las Naciones Unidas para la Alimentación y la Agricultura) (2020). FAOSTAT. Cultivos. http://www.fao.org/faostat/es/\#data/QC.

2. United States Departament of Agricultura (2020). World Agricultural Supply and Demand Estimates. https://www. usda.gov/oce/commodity/wasde/wasde0420.pdf.

3. Dirección de Investigación y Evaluación Económica (2016). Panorama Agroalimentario Maíz 2016, pp. 2-38. Fideicomisos Instituidos en Relación con la Agricultura (FIRA) Bulletin. https:/www.gob.mx/cms/uploads/ attachment/file/200637/Panorama_Agroalimentario_Ma_z_2016.pdf.

4. Villarreal, A., Rodríguez-Herrera, R., Reyes-Valdés, M. H., Espinosa-Velázquez, J., Castillo-Reyes, F. (2010). Xenia y su relación con la poliembrionía en maiz. Revista Cientifica de la Universidad Autónoma de Coahuila, 2(3), 1-7.

5. Arellano-Durán, N., Villegas-Monter, Á., Muñoz-Orozco, A. (2018). Optimum sample size in quantitative characteristics of seeds of polyembryonic mango. Revista Brasileira de Fruticultura, 40(3), 1-8, e519. DOI 10.1590/0100-29452018519.

6. Espinoza Velázquez, J., Valdés Reyna, J., Alcalá Rodríguez, J. M. (2012). Morfologpia y anatomía de radículas múltiples en plántulas de maíz derivadas de cariopsis con poliembrionía. Polibotánica, 33(1), 207-221.

7. Duarte, F. E. V. O., Barros, D. R., Girardi, E. A., Soares-Filho, W. S., Passos, O. S. (2013). Poliembrionia E atributos morfológicos De sementes De porta-enxertos De citros. Revista Brasileira de Fruticultura, 35, 246254. DOI 10.1590/S0100-29452013000100028.

8. Espinoza, J., Vega, C., Navarro, E., Burciaga, G. A. (1998). Poliembrionía en maices de porte normal y enano. Agronomía Mesoamericana, 9(2), 83-88. DOI 10.15517/am.v9i2.20112.

9. Andrade-Rodríguez, M., Villegas-Monter, Á., Gutiérrez-Espinosa, M. A., Carrillo-Castañeda, G., García-Velázquez, A. (2005). Polyembryony and RAPD markers for identification of zygotic and nucellar seedlings in citrus. Agrociencia, 39(6), 371-383. DOI 10.1590/S0100-204X2004000600006. 
10. Hernández, H. R., Velázquez, J. E., Garduño, D. S., Zamora Villa, V. M. (2011). Herencia de la poliembrionía en dos poblaciones experimentales de maíz. Revista Fitotecnia Mexicana, 34, 27-33. DOI 10.35196/rfm.2011.1.27.

11. Avendaño-Sanchez, M., Espinoza-Velázquez, J., Gutiérrez-López, A., Flores-Gallegos, A. C., Rodríguez-Herrera, R. (2017). Secuencias nucleotídicas de la región ITS en familias S1 y PL de maíces poliembriónicos. Revista Mexicana de Ciencias Agricolas, 6(3), 509. DOI 10.29312/remexca.v6i3.635.

12. Alcalá-Rico, J. S. G. J., Espinoza-Velázquez, J., López-Benítez, A., Borrego-Escalante, F., Rodriguez-Herrera, R. et al. (2019). Agronomic performance of maize (Zea mays L.) populations segregating the polyembryony mutant. Revista de la Facultad de Ciencias Agrarias, 51(1), 1-18.

13. Gutiérrez-López, A. J., Espinoza-Velázquez, J., Flores-Gallegos, A. C., López-Benítez, A., Ruiz-Torres, N. A. et al. (2019). Absence of concordance between polyembryony and apomixis in maize confirmed through DNA sequencing. Ecosistemas y Recursos Agropecuarios, 6(18), 451-461. DOI 10.19136/era.a6n18.2111.

14. Maceda-Sánchez, I., Reyes-Valdés, M. H., Ramírez-Godina, F., Reyes-Méndez, C. A., Rodríguez-Herrera, R. et al. (2019). Incomplete penetrance in maize genotypes segregating for the polyembryony trait. Maydica, 64(1), 11.

15. Valdez Lara, E. L., Espinoza Velazquez, J., Reyes Vega, M. D. L. L., García Valdés, A. E., de León Castillo, H. et al. (2005). Asociación entre calidad proteica de grano y poliembrionía en población braquítica de maíz enano. Revista Agraria Nueva Epoca, 2, 40.

16. Michel, M. R., Aguilar-Zárate, P., Espinoza-Velázquez, J., Aguilar Gonzalez, C. N., Rodriguez-Herrera, R. (2020). Environmental effects on chemical composition and physical properties of polyembryonic maize grain. TIP. Revista Especializada en Ciencias Químico-Biológicas, 23(1), 1-9. DOI 10.22201/fesz.23958723e.2020.0.221.

17. Requena, M. C., Rodríguez-Herrera, R., Aguilar-Gonzales, C. N., Espinoza-Velázquez, J., Gaytán-Martínez, M. et al. (2011). Alkaline cooking quality of polyembryonic and non-polyembryonic maize populations. Advance Journal of Food Science and Technology, 3(4), 259-268.

18. Ortiz-Rojas, L. Y., Chaves-Bedoya, G. (2017). Composición fitoquímica del extracto de raíz de ichthyothere terminalis de dos regiones. Revista Colombiana de Química, 46, 11-16. DOI 10.15446/rev.colomb.quim. v46n3.61865.

19. Monroy-Vázquez, M. E., Peña-Valdivia, C. B., García-Nava, J. R., Solano-Camacho, E., Campos, H. et al. (2017). Imbibición, viabilidad y vigor de semillas de cuatro especies de opuntia con grado distinto de domesticación. Agrociencia, 51(1), 27-42.

20. Rosabal Ayan, L., Martínez González, L., Reyes Guerrero, Y., Dell Rodríguez, J., Núñez Vázquez, A. (2014). Revisión bibliográfica. Aspectos fisiológicos, bioquímicos y expresión de genes en condiciones de déficit hídrico. Influencia en el proceso de germinación. Cultivos Tropicales, 35, 24-35.

21. Matilla, J. (2008). Desarrollo y germinación de las semillas. In: Fundamentos de fisiología vegetal, vol. 21, pp. 537-558. Universidad de Santiago de Compostela, Santiago de Compostela, Galicia, Spain.

22. Fenner, M., Thompson, K. (2005). The ecology of seeds. Cambridge, UK: Cambridge University Press.

23. Hatfield, R. D., Ralph, J., Grabber, J. H. (1999). Cell wall cross-linking by ferulates and diferulates in grasses. Journal of the Science of Food and Agriculture, 79, 403-407. DOI 10.1.1.167.9806\&rep=rep1\&type=pdf.

24. Dewick, P. M. (2009). Medicinal natural products: A biosynthentic aooroach. Nueva Jersey, USA: John Wiley \& Sons, Ltd. Hoboken.

25. Dennis, P. G., Miller, A. J., Hirsch, P. R. (2010). Are root exudates more important than other sources of rhizodeposits in structuring rhizosphere bacterial communities? FEMS Microbiology Ecology, 72(3), 313-327. DOI 10.1111/j.1574-6941.2010.00860.x.

26. Kumar, N., Goel, N. (2019). Phenolic acids: natural versatile molecules with promising therapeutic applications. Biotechnology Reports, 24, e00370, DOI 10.1016/j.btre.2019.e00370.

27. Wichers, H. J., Soler-rivas, C., Esp1, J. C. (2000). Review oleuropein and related compounds. Journal of the Science of Food and Agriculture, 80(7), 1013-1023. DOI 10.1002/(SICI)1097-0010(20000515)80:7<1013:: AID-JSFA571>3.0.CO;2-C.

28. Ba, R., Alfa, T., Gbaguidi, F., Novidzro, K. M., Dotse, K. et al. (2017). Maize fungal growth control with scopoletin of cassava roots produced in Benin. International Journal of Microbiology, 2017, 1-11, 5671942. DOI $10.1155 / 2017 / 5671942$. 
29. Goodwin, R. H., Kavanagh, F. (1949). The isolation of scopoletin, a blue-fluorescing compounds of oat root. Bull. Torrey Botanical Club, 76, 255-265.

30. Frangne, N., Eggmann, T., Koblischke, C., Weissenböck, G., Martinoia, E. et al. (2002). Flavone glucoside uptake into barley mesophyll and arabidopsis cell culture vacuoles. Energization occurs by $\mathrm{H}^{+}$-antiport and ATP-binding cassette-type mechanisms. Plant Physiology, 128, 726-733. DOI 10.1104/pp.010590.

31. Lozhnikova, V. N., Kondrat'eva, V. V. (2001). Levels of hydroxycinnamic acids and free auxins in tobacco during photoperiodic induction. Izvestiia Akademii Nauk. Seriia Biologicheskaia/Rossiiskaia Akademiia Nauk, $28,187-190$.

32. Macoy, D. M., Kim, W. Y., Lee, S. Y., Kim, M. G. (2015). Biosynthesis, physiology, and functions of hydroxycinnamic acid amides in plants. Plant Biotechnology Reports, 9, 269-278. DOI 10.1007/s11816-015-0368-1.

33. Fellah, B., Bannour, M., Rocchetti, G., Lucini, L., Ferchichi, A. (2018). Phenolic profiling and antioxidant capacity in flowers, leaves and peels of Tunisian cultivars of Punica granatum L. Journal of Food Science and Technology, 55, 3606-3615. DOI 10.1007/s13197-018-3286-8.

34. Akowuah, G. A., Ismail, Z., Norhayati, I., Sadikun, A. (2005). The effects of different extraction solvents of varying polarities on polyphenols of Orthosiphon stamineus and evaluation of the free radical-scavenging activity. Food Chemistry, 93, 311-317. DOI 10.1016/j.foodchem.2004.09.028.

35. Rösch, D., Krumbein, A., Kroh, L. W. (2004). Antioxidant gallocatechins, dimeric and trimeric proanthocyanidins from sea buckthorn (Hippophaë rhamnoides) pomace. European Food Research and Technology, 219, 605-613. DOI 10.1007/s00217-004-1002-6. 